\title{
Puffins as samplers of juvenile pollock and other forage fish in the Gulf of Alaska
}

\author{
Scott A. Hatch, Gerald A. Sanger ${ }^{\circ}$ \\ Alaska Fish and Wildlife Research Center, U.S. Fish and Wildlife Service, 1011 East Tudor Road, Anchorage, Alaska 99503, USA
}

\begin{abstract}
We sampled the nestling diets of tufted puffins Fratercula cirrhata and horned puffins F. corniculata in 3 years at colonies from the north-central Gulf of Alaska to the eastern Aleutian Islands, Alaska, USA. Overall, tufted puffins consumed (by weight) $41 \%$ sandlance Ammodytes hexapterus, $22 \%$ capelin Mallotus villosus, $19 \%$ walleye pollock Theragra chalcogramma, $13 \%$ other fish, and $5 \%$ invertebrates, whereas horned puffins took $85 \%$ sandlance, $4 \%$ capelin, $2 \%$ pollock, $8 \%$ other fish, and $<1 \%$ invertebrates. All of the pollock consumed were young of the year, whereas 4 year-classes of capelin were present, from young of the year through spawning adults. Puffins took mostly first-year sandlance, but fish in their second year or older were also common at colonies near Kodiak, Alaska. The importance of juvenile pollock in the diet of tufted puffins varied geographically from little or no use in the north-central Gulf and Kodiak areas to moderate use (5 to $20 \%$ ) in the Semidi and Shumagin Islands to heavy use $(25$ to $75 \%)$ in the Sandman Reefs and eastern Aleutians. An estimated 11 billion pollock were consumed by tufted puffins throughout the region in 1986 . The proportion of pollock in puffin diets at the Semidi Islands was strongly correlated with independent estimates of cohort strength in 3 years. Puffins may thus provide a useful index of distribution and yearclass abundance of first-year pollock, a species that currently supports an important commercial fishery in the Gulf of Alaska.
\end{abstract}

\section{INTRODUCTION}

Puffins feed mostly fish to their young, and they usually depend on one or a small number of prey species for the bulk of the chicks' diet. Not infrequently, those key prey species are also subject to commercial harvest by man, leading to potential conflicts between fisheries management and seabird conservation. For example, known or suspected conflicts have occurred involving Atlantic puffins Fratercula arctica and commercially exploited fish stocks such as herring Clupea harengus off northern Norway (Anker-Nilssen 1987, Barrett et al. 1987, AnkerNilssen \& Lorentsen 1990\}, sandlance Ammodytes marinus near the Shetland Islands, Scotland (Martin 1989), and capelin Mallotus villosus on the east coast of Canada (Nettleship 1991).

Capelin and Pacific sandlance Ammodytes hexapterus are important foods of puffins in Alaska (Wehle 1983, Hatch 1984, Baird 1990), but neither species is

-Present address: PO Box 652, Whittier, Alaska 99693, USA presently targeted by commercial fisheries. In contrast, walleye pollock Theragra chalcogramma, a species of considerable importance to puffins (see below), currently supports the world's largest single-species fishery, with annual landings exceeding 5 million metric $t$ since the early 1980's (Lloyd \& Davis 1989). A pollock fishery in the Gulf of Alaska developed rapidly after 1980, when a large spawning concentration was discovered in lower Shelikof Strait between Kodiak Island and the Alaska mainland (Fig. 1; Kendall et al. 1987). Spawning peaks in early April, and the southwesterly drift of eggs and larvae is such that juvenile pollock are potentially available to puffins and other seabirds along the Alaska Peninsula in midsummer (Kendall \& Picquelle 1989, Hinckley et al. 1991).

We sampled puffins at colonies in this region over 3 years to determine patterns of prey use during the nestling period. The emphasis was on tufted puffins Fratercula cirrhata, but we also obtained material from horned puffins F. corniculata in 2 colonies. In this paper we document species, area, and annual variation in puffin nestling diets in the Gulf of Alaska, estimate 


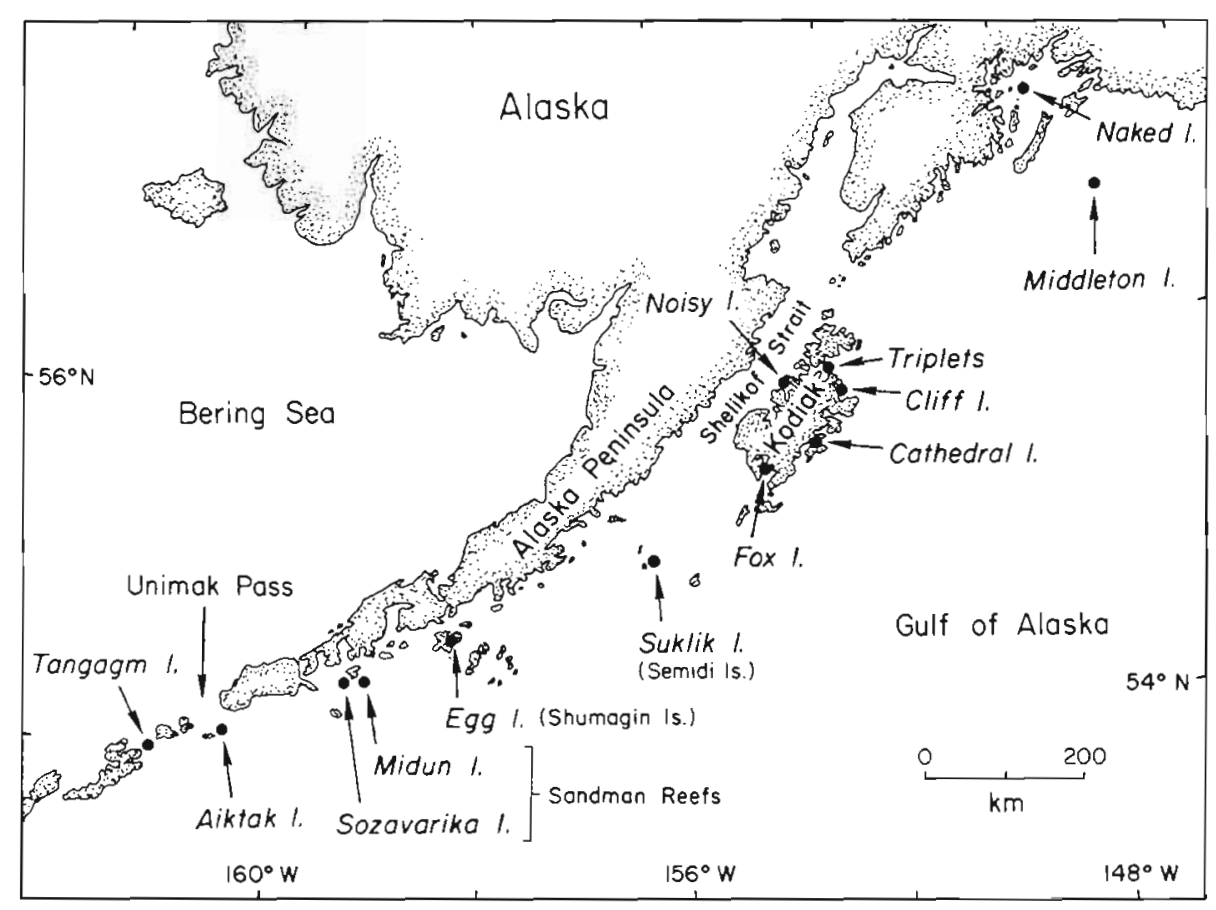

Fig. 1. Western Gulf of Alaska and eastern Aleutian Islands, indicating sampling sites for puffin diet studies and other locations mentioned in text

total consumption by puffins of juvenile pollock during the chick-rearing period, and evaluate whether the sampling of puffin diets is a useful method for estimating the year-class strength of walleye pollock.

\section{METHODS}

Between 1985 and 1987, we sampled the diets of nestling puffins in 13 colonies from Middleton Island, north-central Gulf of Alaska, to Tangagm Island in the Baby Islands near Unimak Pass (Fig. 1). Collections were limited in 1985 to Suklik Island (Semidi Islands), where both puffin species were available for sampling. The following year we visited Suklik and 11 additional colonies of tufted puffins. In 1987 we reduced the sampling scheme to emphasize sites in the region of heaviest pollock use in 1986.

Most sampling occurred over 2 to $3 \mathrm{wk}$ from mid to late August (Table 1). Usually only 1 to $3 d$ were spent at a given colony each year, with 3 notable exceptions: Suklik Island in 1985 (10 d) and 1987 (29 d), and Aiktak Island in 1987 (9 d). Extended stays were used to document daily and seasonal variation in diet composition.

The principal method we used to collect chick meals was to block the entrances of puffin burrows to prevent food-carrying adults from entering. Many puffins returning to blocked burrows dropped their bill loads at the entrance. We made re-usable screens of gal- vanized hardware cloth $(1.25 \mathrm{~cm}$ mesh), sized appropriately for tufted puffins (about $18 \times 20 \mathrm{~cm}$ ) or horned puffins $(15 \times 18 \mathrm{~cm})$. The corners of a screen were pressed into the sod around a burrow entrance to make a firm barrier. Screened burrows were marked to aid in relocation. Food samples were collected and the screens removed after about $2 \mathrm{~h}$. Since we could not be sure if a particular sample was a partial bill load, 1 full load, or more than 1 load, we refer to the samples as screen loads.

The usual procedure was to screen 50 to 200 burrow entrances at dawn, because puffins generally exhibit a morning peak in food deliveries (Corkhill 1973, Harris \& Hislop 1978, Wehle 1983). Some sampling was done at other times of day to check for diurnal changes in diet composition. We tested for diurnal and seasonal variation in diet composition using 2-way ANOVAs on rank-transformed daily percentages of the major prey types. Thus, each factor (date or time) was controlled before testing the significance of the other. Times were grouped as forenoon or afternoon; the mean composition of each day's samples comprised a separate category of the factor 'date'.

The screen technique is effective for burrow-nesting species, but horned puffins usually nest in rock crevices. We were able to apply the method to both puffin species in this study because horned puffins used burrows extensively on 2 islands (Suklik Island and Sozavarika $a_{i}$ Hatch \& Hatch 1983). In addition to 
Table 1. Fratercula cirrhata, F. corniculata. Sampling dates and sample sizes by colony

\begin{tabular}{|c|c|c|c|c|c|c|}
\hline \multirow[t]{2}{*}{ Location } & \multirow[t]{2}{*}{ Year } & \multirow[t]{2}{*}{ Sampling dates } & \multicolumn{2}{|c|}{ Tufted puffin } & \multicolumn{2}{|c|}{ Horned puffin } \\
\hline & & & No. samples & Total weight (g) & No. samples & Total weight $(g)$ \\
\hline \multirow{2}{*}{ Middleton I. } & 1986 & $2 \mathrm{Aug}$ & 3 & 23 & - & - \\
\hline & 1987 & 3 Jul - 6 Aug & 6 & 94 & - & - \\
\hline Naked I. & 1986 & 13 Aug & 2 & 11 & - & - \\
\hline The Triplets & 1986 & 2 Aug; $_{2}-3 \mathrm{Sep}$ & 32 & 260 & - & - \\
\hline Noisy I. & 1986 & 11 Aug & 12 & 74 & - & - \\
\hline Cliff I. & 1986 & 4-5 Aug; 5-6 Sep & 34 & 529 & - & - \\
\hline Cathedral I. & 1986 & $29-31$ Aug & 39 & 384 & - & - \\
\hline Fox I. & 1986 & 21-22 Aug & 11 & 98 & - & - \\
\hline \multirow[t]{3}{*}{ Suklik I. } & 1985 & $17-26$ Aug & 187 & 1455 & 131 & 1579 \\
\hline & 1986 & $11-13 \mathrm{Aug}$ & 125 & 935 & 65 & 527 \\
\hline & 1987 & $29 \mathrm{Jul}-26 \mathrm{Aug}$ & 310 & 1260 & 384 & 2009 \\
\hline \multirow[t]{2}{*}{ Egg I. } & 1986 & $21-22$ Aug & 67 & 610 & - & - \\
\hline & 1987 & $8-11$ Aug & 17 & 79 & - & - \\
\hline \multirow[t]{2}{*}{ Midun I. } & 1986 & $24-25$ Aug & 106 & 716 & - & - \\
\hline & 1987 & $14-17$ Aug & 54 & 374 & - & - \\
\hline Sozavarika I. & 1987 & $18-20 \mathrm{Aug}$ & 16 & 118 & 39 & 223 \\
\hline \multirow[t]{2}{*}{ Aiktak I. } & 1986 & 1-2 Sep & 108 & 796 & - & - \\
\hline & 1987 & 27 Aug - 5 Sep & 335 & 2447 & - & - \\
\hline Tangagm I. & 1986 & 30-31 Aug; 3 Sep & 52 & 365 & - & - \\
\hline
\end{tabular}

the screen loads, we collected a few bill loads from returning puffins that we startled and stray samples on the ground (Table 2).

All samples were washed, fixed in $5 \%$ buffered formaldehyde solution for 12 to $24 \mathrm{~h}$, then stored in $50 \%$ isopropanol for later examination in the lab. A few individuals of common prey species were weighed and measured in the field to establish weight-length relationships in fresh material. Other samples were weighed fresh and reweighed in the lab to determine the effect of preservation. We found a mean change of $-15 \%$ in fish weights after preservation. Unless otherwise indicated, the data presented are preserved weights.

Prey were identified to the lowest possible taxon. Unidentified prey, and voucher specimens of species we tentatively identified were sent to taxonomic specialists at the Alaska Fisheries Science Center,

Table 2. Summary of return on sampling effort in puffin diet studies conducted in the Gulf of Alaska, 1985-1987

\begin{tabular}{|c|c|c|c|c|c|c|c|c|}
\hline & \multicolumn{4}{|c|}{ Tufted puffin } & \multicolumn{4}{|c|}{ Horned puffin } \\
\hline & 1985 & 1986 & 1987 & All years & 1985 & 1986 & 1987 & All years \\
\hline Colonies visited & 1 & 12 & 6 & 13 & 1 & 1 & 2 & 2 \\
\hline \multicolumn{9}{|l|}{ Samples obtained } \\
\hline Screen & 175 & 572 & 606 & 1353 & 55 & 62 & 340 & 457 \\
\hline Bill & 12 & 5 & 0 & 17 & 64 & 0 & 0 & 64 \\
\hline Ground & 0 & 14 & 132 & 146 & 12 & 3 & 83 & 98 \\
\hline Total & 187 & 591 & 738 & 1516 & 131 & 65 & 423 & 619 \\
\hline Total prey items & 1975 & 3923 & 3372 & 9270 & 1962 & 944 & 1829 & 4735 \\
\hline \multicolumn{9}{|l|}{ Prey species encountered } \\
\hline Fish & 6 & 15 & 27 & 32 & 5 & 5 & 13 & 13 \\
\hline Invertebrates ${ }^{a}$ & 3 & 4 & 7 & 7 & 1 & 0 & 2 & 2 \\
\hline Total sample weight $(g)^{b}$ & 1455 & 4800 & 4371 & 10626 & 1579 & 527 & 2232 & 4338 \\
\hline \multicolumn{9}{|l|}{ Mean load size $e^{c}$} \\
\hline Weight (g) & 7.7 & 8.2 & 6.4 & 7.3 & 9.2 & 8.3 & 5.7 & 6.5 \\
\hline No. items & 10.4 & 6.6 & 5.1 & 6.4 & 13.0 & 14.9 & 4.7 & 7.1 \\
\hline Mean prey species per sample & 1.9 & 1.5 & 1.7 & 1.6 & 1.4 & 1.2 & 1.2 & 1.2 \\
\hline \multicolumn{9}{|c|}{ a Not all cephalopods were identified to species } \\
\hline \multicolumn{9}{|c|}{${ }^{b}$ Preserved weights } \\
\hline 'Screen samples only & & & & & & & & \\
\hline
\end{tabular}


National Marine Fisheries Service, Seattle, Washington, USA, for verification. Total lengths of individual prey were measured to the nearest $\mathrm{mm}$; total samples and the portion of each prey type they contained were weighed to the nearest $0.1 \mathrm{~g}$. To express the importance of a prey type from 1 site and year we used a pooled sample proportion - total weight of the prey divided by total weight of all samples collected. Where samples $(n>15)$ from different siteyears are combined for comparisons, we used an unweighted mean of the proportions established for each site-year.

\section{RESULTS}

\section{Diet composition - species, area, and year effects}

Tufted puffins fed their chicks a greater variety of prey than horned puffins, the latter being primarily a sandlance feeder (Fig. 2). The difference was most pronounced on Suklik Island in 1985, when horned puffins fed $83 \%$ sandlance to their chicks, whereas

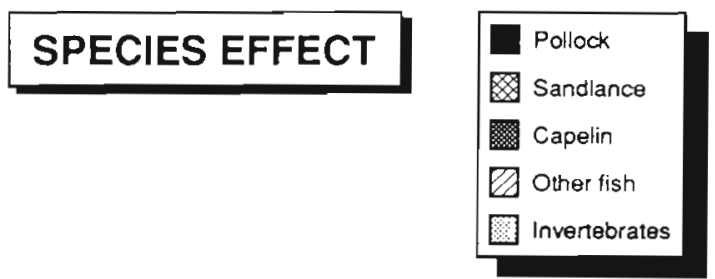

Suklik I. (1985-1987)

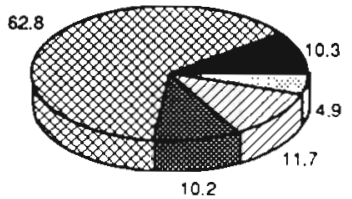

$n=622$

Sozavarika I. (1987)

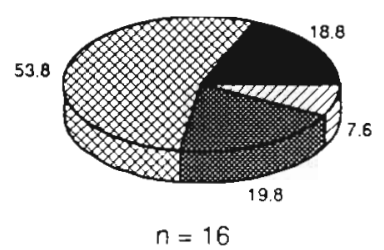

Tufted Puffin
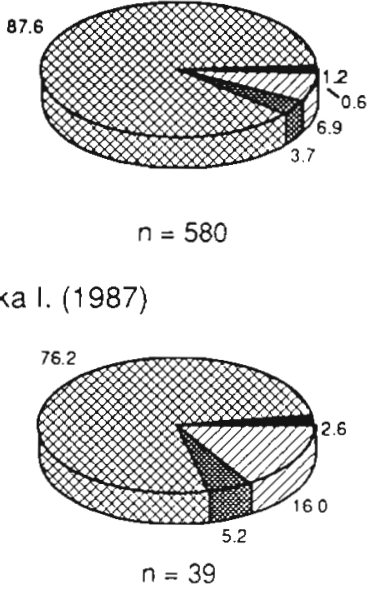

Horned Puffin
Fig. 2. Fratercula cirrhata, F corniculata. Percent composition of tufted and horned puffin nestling diets at 2 colonies in the western Gulf of Alaska. Data from 3 yr on Suklik Island are pooled for comparison of species tufted puffins took $48 \%$ sandlance and substantial quantities of several other fish species and invertebrates. In all, tufted puffins took 32 fish species and 7 kinds of invertebrates, including 2 species of polychaetes, 2 euphausiids, shrimp, octopus, and squid (Tables 2 \& 3). We found 13 species of fish and 2 invertebrates (euphausiids and squid) in horned puffin food loads. The average screen load in both species weighed about $7 \mathrm{~g}$ and contained 6 to 7 prey items (Table 2).

The most important prey of tufted puffins were sandlance, capelin, and walleye pollock. The combination of those 3 species was a consistently high proportion (73 to $98 \%$ ) of the nestling diets sampled at 4 colonies in 2 yr (Table 4). The dominant prey species, however, differed markedly among sites (Fig. 3): sandlance at Suklik (Semidi Islands), capelin at Egg Island (Shumagin Islands), and pollock at Midun and Aiktak (Sandman Reefs and eastern Aleutians, respectively) (Fig. 3). The dominant prey species at a given colony was the same in different years, with the exception of Midun Island. Pollock was the major prey at Midun in 1986, whereas capelin predominated the foilowing year (Table 4).

Sites northeast of the Semidi Islands were sampled less intensively, but our data indicate that sandlance and capelin were the main prey in 1986; pollock generally occurred in only trace amounts (Table 5). Because of small sample sizes from some colonies, pooled sample estimates are preferred for characterizing tufted puffin diets in the region.

Combining data from 4 colonies (Suklik, Egg, Midun, and Aiktak Islands) in 1986 and 1987, we found shifts in the relative amounts of sandlance, capelin, and pollock consumed by tufted puffins (Fig. 4). Although these 3 species comprised about $87 \%$ of the diet in both years, the decrease in the proportion of pollock taken $20 \%$ in 1987 versus $40 \%$ in 1986) was compensated for by increased amounts of sandlance $(10 \%)$ and capelin $(10 \%)$.

Changes in the proportions of fish species at different colonies were not entirely concordant between years. Whereas sandlance increased in importance between 1986 and 1987 at Egg, Midun, and Aiktak Islands, they declined at Suklik Island in the Semidis (Table 4). Pollock declined at Midun and Aiktak between years but were relatively unchanged at the Semidis and Egg Island. Finally, capelin increased at 2 sites (Semidis and Midun Island), declined at 1 site (Egg Island), and remained unchanged at 1 site (Aiktak Island).

Composite results from different sites and years suggest there is an east to west gradient of increasing pollock consumption by puffins in the Gulf (Fig. 5) 


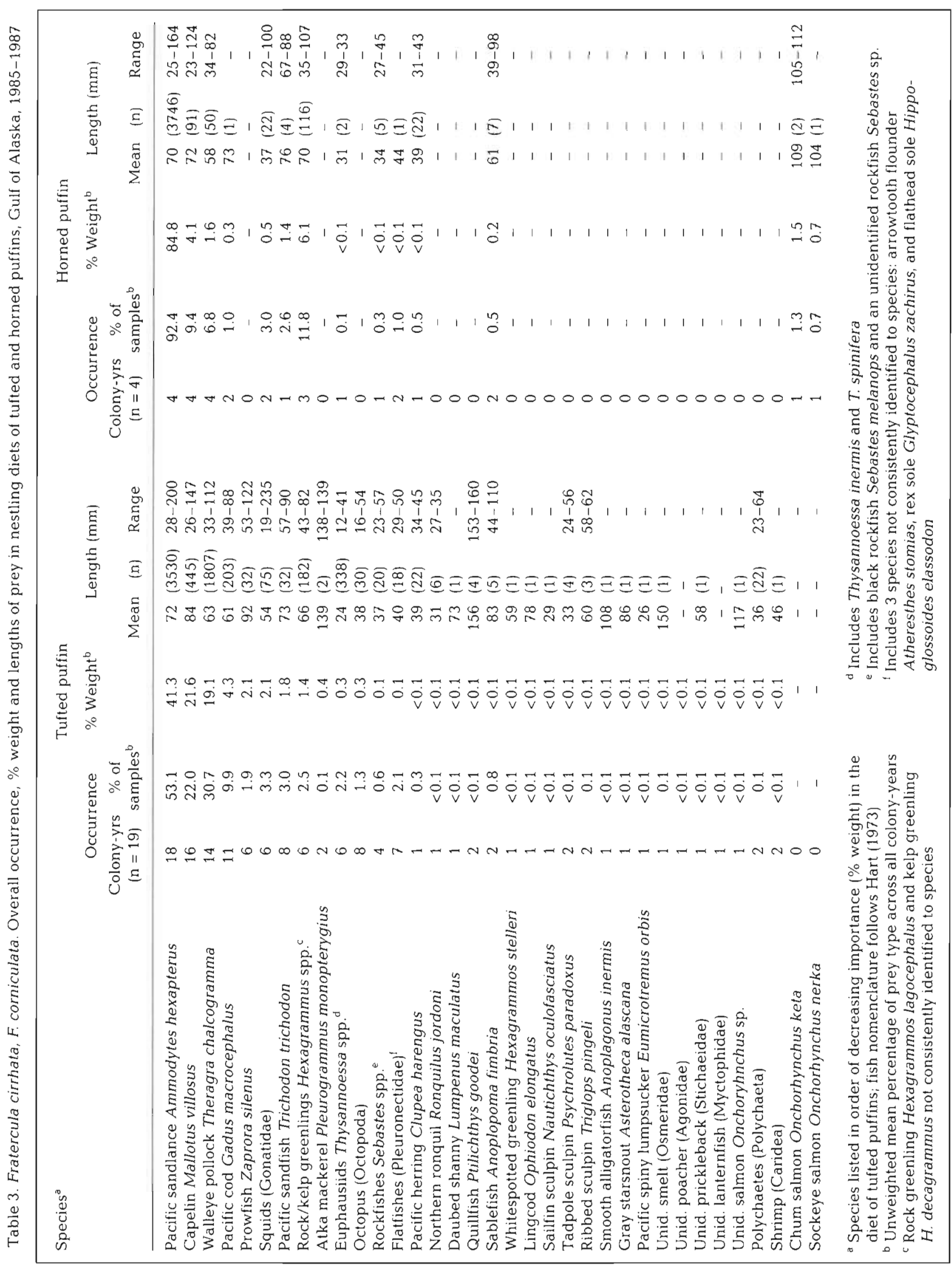


Table 4. Fratercula cirrhata. Composition of tufted puffin nestling diets at 4 locations in the western Gulf of Alaska, 1986-1987

\begin{tabular}{|c|c|c|c|c|c|c|c|c|}
\hline \multirow[t]{2}{*}{ Colony, year } & \multicolumn{5}{|c|}{$\%$ Weight } & \multirow{2}{*}{$\begin{array}{c}\text { Sum of } \\
\text { sandlance, } \\
\text { pollock, } \\
\text { capelin }\end{array}$} & \multirow{2}{*}{$\begin{array}{c}\text { No. } \\
\text { samples }\end{array}$} & \multirow{2}{*}{$\begin{array}{c}\text { Total } \\
\text { sample } \\
\text { weight }(g)\end{array}$} \\
\hline & Sandlance & Pollock & Capelin & $\begin{array}{l}\text { Other } \\
\text { fish }\end{array}$ & $\begin{array}{l}\text { Inverte- } \\
\text { brates }\end{array}$ & & & \\
\hline $\begin{array}{l}\text { Suklik, } 1986 \\
\text { Change }(1986-1987)^{a}\end{array}$ & $\begin{array}{r}84.3 \\
-6\end{array}$ & $\begin{array}{r}5.2 \\
\text { ns }\end{array}$ & $\begin{array}{r}2.2 \\
+c\end{array}$ & 7.3 & 1.0 & 91.7 & 125 & 935 \\
\hline Suklik, 1987 & 56.0 & 5.1 & 19.7 & 9.8 & 9.4 & 80.8 & 310 & 1260 \\
\hline $\begin{array}{l}\text { Egg, } 1986 \\
\text { Change }(1986-1987)^{a}\end{array}$ & $\begin{array}{r}7.0 \\
+b\end{array}$ & $\begin{array}{r}6.3 \\
\text { ns }\end{array}$ & $\begin{array}{r}74.1 \\
-\mathrm{d}\end{array}$ & 12.6 & 0 & 87.4 & 67 & 610 \\
\hline Egg 1987 & 34.5 & 0 & 63.1 & 0 & 2.4 & 97.6 & 17 & 79 \\
\hline $\begin{array}{l}\text { Midun, } 1986 \\
\text { Change }(1986-1987)^{\mathrm{a}}\end{array}$ & $\begin{array}{r}2.6 \\
+{ }^{b}\end{array}$ & $\begin{array}{r}70.2 \\
-\mathrm{b}\end{array}$ & $\begin{array}{r}15.2 \\
+c\end{array}$ & 11.8 & 0.2 & 88.0 & 106 & 716 \\
\hline Midun, 1987 & 28.6 & 26.4 & 41.6 & 3.2 & 0.1 & 96.6 & 54 & 374 \\
\hline $\begin{array}{l}\text { Aiktak, } 1986 \\
\text { Change }(1986-1987)^{\text {a }}\end{array}$ & $\begin{array}{r}8.6 \\
+b\end{array}$ & $\begin{array}{r}74.5 \\
-6\end{array}$ & $\begin{array}{l}0 \\
n s\end{array}$ & 16.7 & 0.2 & 83.1 & 108 & 796 \\
\hline Aiktak, 1987 & 27.6 & 45.3 & 0.4 & 18.9 & 7.8 & 73.3 & 335 & 2447 \\
\hline $\begin{array}{l}\text { ' 't' indicates increase } \\
{ }^{b} p<0.001 \text {; } t \text {-test of diff } \\
\text { per food load) } \\
\text { Test performed as in } \\
\text { dest performed as in } f \\
\text { ns: not significant }\end{array}$ & $\begin{array}{l}\text { etween year } \\
\text { rence betwe } \\
\text { cotnote }^{b}: \hat{p}< \\
\text { otnote }^{b}: p<\end{array}$ & $\begin{array}{l}\text { s, '-' indic } \\
\text { en } 1986 \text { a } \\
0.01 \\
0.05\end{array}$ & $\begin{array}{l}\text { tes decreas } \\
\text { d } 1987 \text { (cor }\end{array}$ & paring $n$ & eans of arc & -transformed & rcentages & prey type \\
\hline
\end{tabular}

Time of day and seasonal effects

\section{AREA EFFECT Years Pooled}

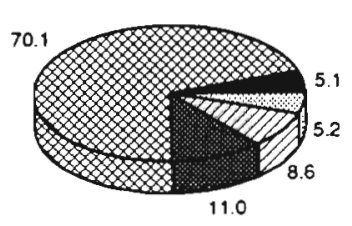

Suklik $(n=435)$

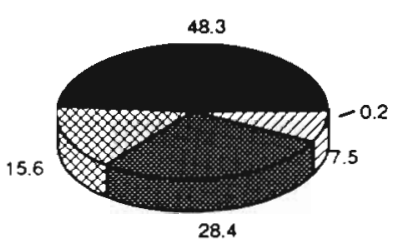

Midun $(n=160)$

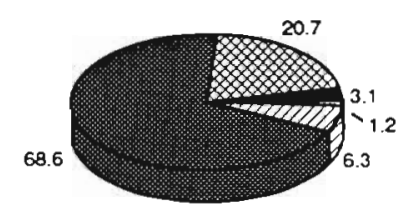

Egg $(n=84)$

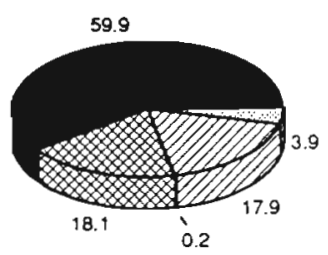

Aiktak $(n=443)$

Fig. 3. Fratercula cirrhata. Percent composition of tufted puffin nestling diets at 4 colonies sampled in 2 years. Data from 1986 and 1987 are pooled for the comparison of sites

We examined data for tufted puffins from Suklik and Aiktak Islands in 1987 for evidence of diurnal and seasonal variation in diet composition (see 'Methods'). The proportion of sandlance showed significant daily variation at Suklik Island $\left(F_{23,274}=1.58, p<0.05\right)$, as did sandlance $\left(F_{8,323}=9.74, p<0.001\right)$ and pollock $\left(F_{8,323}=4.99, \mathrm{p}<0.001\right)$ at Aiktak. The only significant outcome for time of day was a higher proportion of capelin obtained in morning than afternoon hours on Suklik $\left(F_{1,274}=6.28, \mathrm{p}<0.05\right)$.

Correlations of sandlance, pollock, and capelin with calendar date at both sites were uniformly low (maximum $r^{2}=0.16$ ) and nonsignificant. Thus, although the composition of samples was subject to change from day to day, we found no evidence of seasonal trends in respective sampling periods of 10 and $29 \mathrm{~d}$.

\section{Lengths and age classes of prey}

Puffins generally took fish in the size range of 30 to $150 \mathrm{~mm}$ (Table 3). Occasionally they delivered smaller prey such as larval capelin (25 to $40 \mathrm{~mm}$ ) or euphausiids (12 to $41 \mathrm{~mm}$ ). We found little difference between puffin species in prey lengths from samples collected in the same years and locations. Lengths of sandlance 
Table 5. Fratercula cirrhata. Composition of tufted puffin nestling diets at 7 locations in the northern Gulf of Alaska and Kodiak archipelago in 1986

\begin{tabular}{|c|c|c|c|c|c|c|c|c|c|}
\hline \multirow[t]{2}{*}{ Prey species } & \multirow[b]{2}{*}{ Middleton } & \multirow[b]{2}{*}{ Naked } & \multicolumn{3}{|c|}{$\%$ Weight } & \multirow[b]{2}{*}{ Cathedral } & \multirow[b]{2}{*}{ Fox } & \multicolumn{2}{|c|}{ All areas ( $\%$ weight $)$} \\
\hline & & & Triplets & Noisy & Cliff & & & $\begin{array}{c}\text { Pooled } \\
\text { samples }\end{array}$ & $\begin{array}{c}\text { Mean } \\
\text { percentage }\end{array}$ \\
\hline Sandlance & 94.4 & 0 & 53.2 & 32.5 & 40.1 & 84.5 & 42.6 & 55.3 & 49.6 \\
\hline Pollock & 4.7 & 24.1 & 0 & 1.6 & 0 & 1.3 & 0 & 0.7 & 4.5 \\
\hline Capelin & 0 & 0 & 37.0 & 35.1 & 57.7 & 1.1 & 16.9 & 32.5 & 21.1 \\
\hline Other fish & 0.9 & $75.9^{\mathrm{a}}$ & 9.7 & 6.3 & 2.3 & 1.2 .6 & 40.6 & 10.1 & 21.2 \\
\hline Invertebrates & 0 & 0 & 0.1 & 24.5 & 0 & 0.5 & 0 & 1.4 & 3.6 \\
\hline No. samples & 3 & 2 & 32 & 12 & 34 & 39 & 11 & & 133 \\
\hline Total weight (g) & 23.4 & 11.2 & 260.3 & 73.6 & 529.4 & 383.7 & 98.2 & & 1379.8 \\
\hline
\end{tabular}

taken at Sozavarika Island in 1987 were similar, as were sandlance, capelin, and greenlings (Hexagrammidae) taken at Suklik from 1985 to 1987 . There was, however, a small difference in the lengths of pollock taken at Suklik (means of $55.4 \mathrm{~mm}$ in tufted puffins and $58.5 \mathrm{~mm}$ in horned puffins; $F_{1,469}=4.70$, $\mathrm{p}=0.031$ ).

There were small but significant differences in the mean lengths of pollock in tufted puffin samples from different collection sites and years (range of means 51.6 to $\left.70.6 \mathrm{~mm} ; F_{8,1783}=122.83, \mathrm{p}<0.001\right)$. Sample means varied more noticeably in sandlance (range of means 64.1 to $111.5 \mathrm{~mm} ; F_{12,7220}=327.50, \mathrm{p}<0.001$ ) and capelin (range of means 66.6 to $126.1 \mathrm{~mm} ; F_{6.472}=$ 68.98, $p<0.001$ ). Mean pollock lengths were corre-

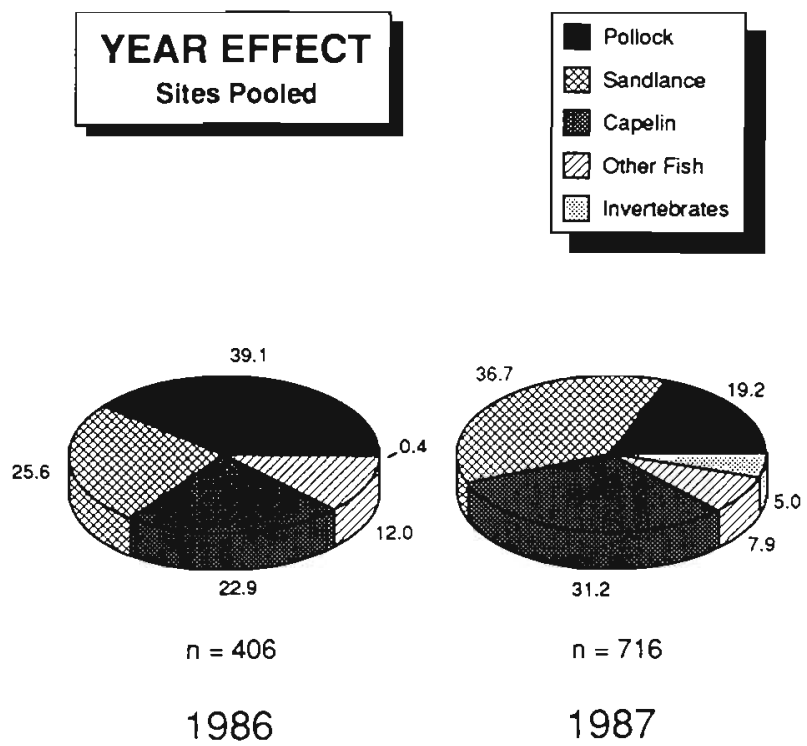

Fig. 4. Fratercula cirrhata. Percent composition of nestling diets during 2 years in the western Gulf of Alaska. Data from 4 sites (Suklik, Egg, Midun, Aiktak) are pooled for comparison of years lated with mean collection dates at 5 sites in 1986 and at 3 sites in 1987 (Fig. 6), suggesting the variation in that species could be explained by growth of individual pollock (see below).

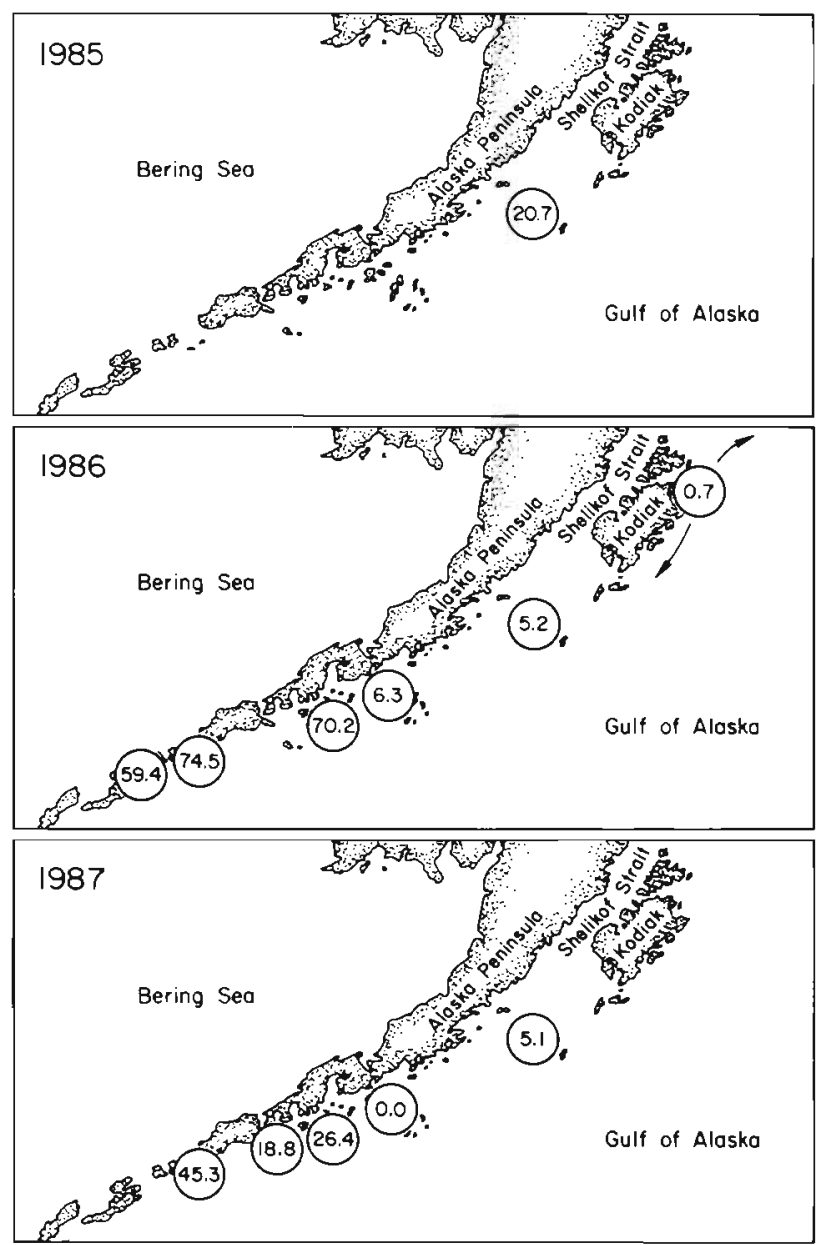

Fig. 5. Theragra chalcogramma, Fratercula cirrhata. Proportions of pollock in tufted puffin nestling diets, illustrating an east-west gradient of pollock use in the Gulf of Alaska 


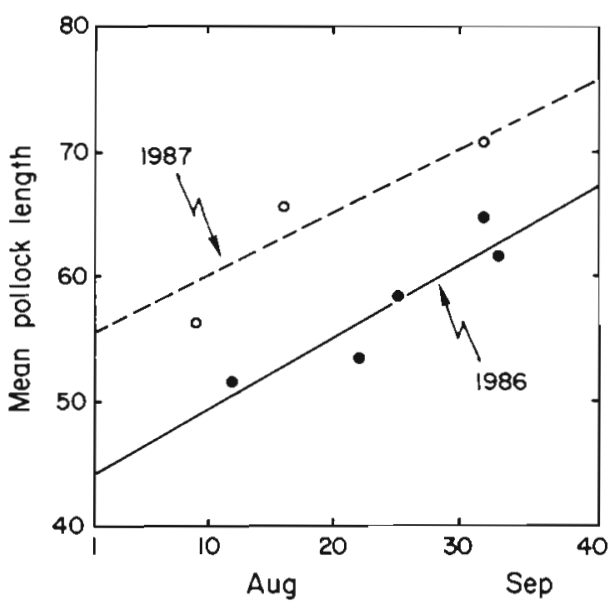

Fig. 6. Theragra chalcograma. Mean lengths of juvenile pollock in relation to mean sampling dates at puffin colonies in the Gulf of Alaska during 1986 and 1987

All pollock taken by puffins were Age 0 juveniles (Fig. 7). At least 3 age-classes of sandlance were present, although hatching-year juveniles far outnumbered older fish (Fig. 8). Four modes in the iengthfrequency distribution of capelin correspond to Ages 0 to 3 (Fig. 9). Capelin in Alaska become sexually mature at Age 2 or 3 (Pahlke 1985), so puffins fed extensively on adults as well as juveniles of that species.

Puffins in the Kodiak area (Cliff and Cathedral Islands and the Triplets) took older capelin and sandlance more frequently than those along the Alaska Peninsula ( 10 colonies from Suklik Island to Tangagm). The result was sharply contrasting age distributions of prey biomass. Whereas Age 1 or older fish made up $95 \%$ of the sandlance biomass delivered in Kodiak colonies, the largest component was Age 0 fish along the Alaska Peninsula (Fig. 10). Similarly, about $80 \%$ of the capelin biomass near Kodiak was Age 3 fish, while Age 2 capelin contributed most of the bulk in the other colonies we sampled (Fig. 11).

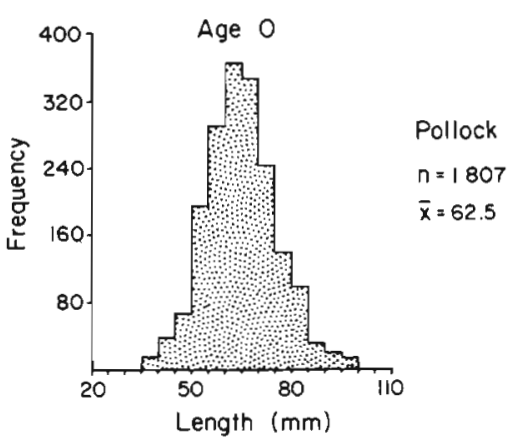

Fig. 7. Theragra chalcogramma. Length-frequency distribution of walleye pollock in tufted puffin diets in the Gulf of Alaska. Combined data from 14 colony-years, 1985-1987. Assignment of juvenile pollock to Age 0 group based on ageat-length data in Walline (1983)

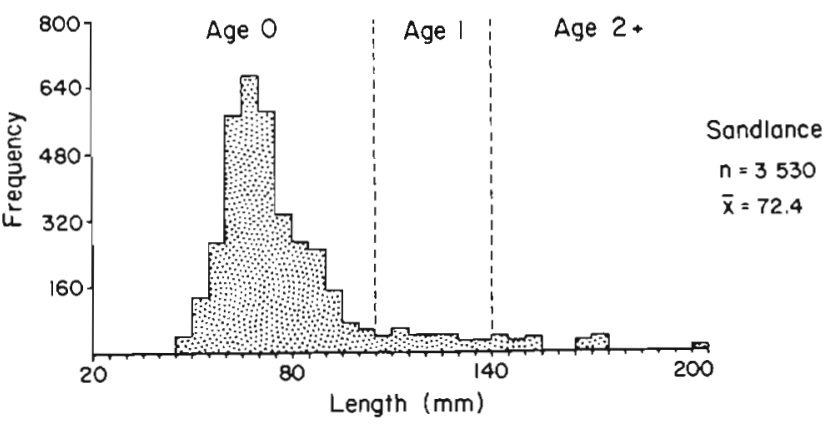

Fig. 8. Ammodytes hexapterus. Length-frequency distribution and age classes of Pacific sandlance in tufted puffin diets in the Gulf of Alaska. Combined data from 18 colony-years, 1985-1987. Age determinations based on age-at-length data in Dick \& Warner (1982)

\section{Pollock growth rates}

Because all the pollock collected in a given year were of a single cohort (Age 0 juveniles), it is possible to estimate their daily growth increments. We used 2 methods, the firsi veing a hineâr reğiessioñ of ârea mean lengths and mean collection dates for sites visited in 1986 and 1987 (Fig. 6). This assumes that fish from all areas were hatched at the same time and that conditions for growth were similar throughout the region. Secondly, we computed regressions of daily mean lengths and calendar date for 2 sites with extended sampling periods (Suklik Island in 1985 and 1987, and Aiktak Island in 1987). Estimates from either method pertain to the size range of juvenile pollock taken by puffins, which may differ from the size distribution in the population at large. Five estimates of pollock growth ranged from 0.49 to $1.15 \mathrm{~mm} \mathrm{day}^{-1}$, the 2 highest values being the longitudinal estimates from Suklik (Table 6).

About $85 \%$ of the variation in area mean lengths was explained by sampling date, consistent with the

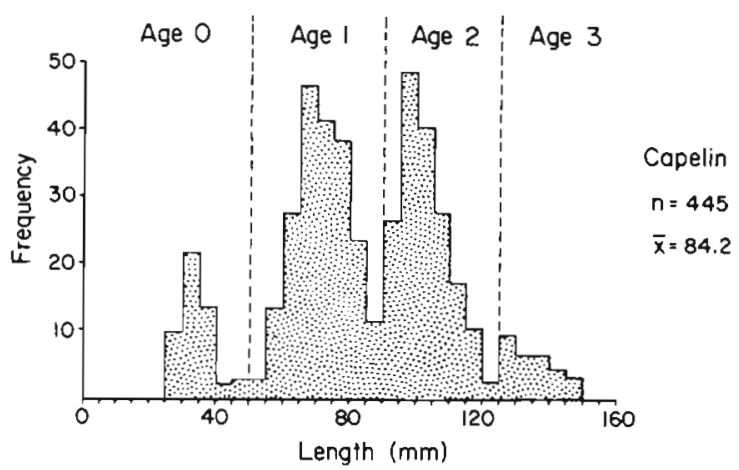

Fig. 9. Mallotus villosus. Length-frequency distribution and age classes of capelin in tufted puffin diets in the Gulf of Alaska. Combined data from 16 colony-years, 1985-1987. Age determination based on age-at-length data in Pahlke (1985) 


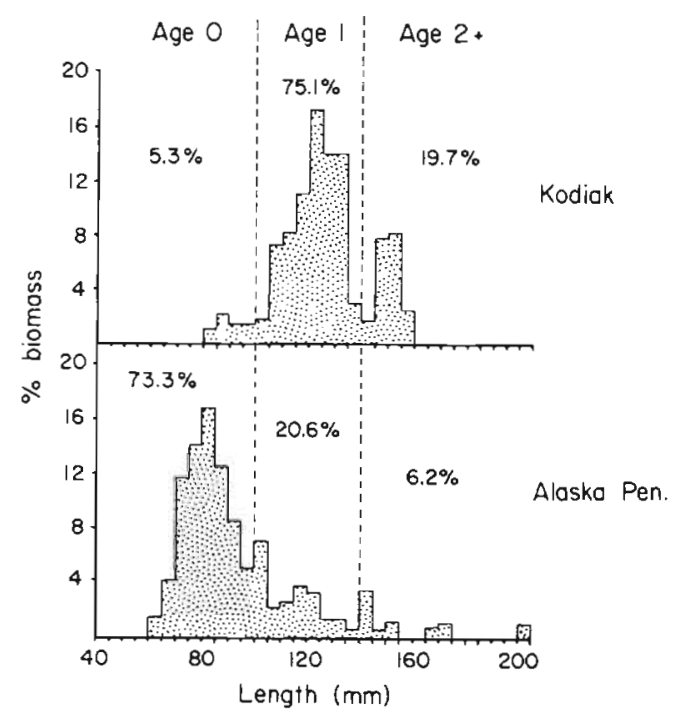

Fig. 10. Ammodytes hexapterus. Age distribution of sandlance biomass in tufted puffin diets compared between colonies near Kodiak and those along the Alaska Peninsula. Length-frequency data converted to biomass using weightlength relationships obtained from fresh specimens measured in this study $\left[\mathrm{W}=7.603 \mathrm{~L}^{3.296} \times 10^{-7} ; \mathrm{W}\right.$ : weight $(\mathrm{g})$; $\mathrm{L}$ : total length $(\mathrm{mm})]$

possibility that pollock from all areas comprised a unit stock. In an analysis of covariance, however, significant differences among areas remained after adjusting for calendar date $\left(F_{4,839}=6.87, \mathrm{p}<0.001\right.$ in $1986 ; F_{2,590}$ $=5.66, \mathrm{p}<0.01$ in 1987).

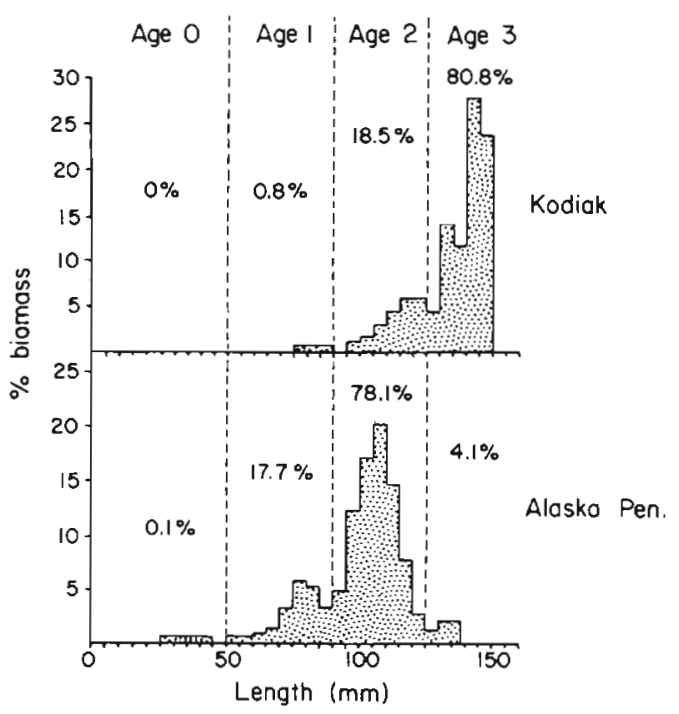

Fig. 11. Mallotus villosus. Age distribution of capelin biomass in tufted puffin diets compared between colonies near Kodiak and those along the Alaska Peninsula. Length-frequency data converted to biomass using weight-length relationships obtained from fresh specimens measured in this study $(\mathrm{W}=$ $4.024 \mathrm{~L}^{3522} \times 10^{-7}: \mathrm{W}$ : weight $(\mathrm{g})$; L: total length $\left.(\mathrm{mm})\right]$

\section{Estimating pollock consumption by puffins}

To estimate pollock consumption by tufted puffins during chick-rearing in the Gulf, we divided the region into areas of light, moderate, and heavy pollock use (Fig. 12). Area 1 includes colonies from the northcentral Gulf and Prince William Sound through the Kodiak archipelago. Area 2 is bounded approximately by the Semidi Islands and Shumagin Islands, and Area 3, with the heaviest pollock use and largest puffin population, extends from the Sandman Reefs through the eastern Aleutians.

Our calculation of pollock consumption rests on the following assumptions: (1) The diets of adult and nestling puffins during chick rearing are the same. (2) The composition of the diet is constant over the whole chick-rearing period, which in the Gulf of Alaska lasts about $60 \mathrm{~d}$ from mid July to mid September. (3) An adult puffin weighs $775 \mathrm{~g}$ (Wehle 1980) and has a daily energy requirement consistent with the allometric equation for cold water seabirds using flapping flight (Birt-Friesen et al. 1989): $\log y=3.24+0.727 \log x$, where $y=$ field metabolic rate $\left(\mathrm{kJ} \mathrm{d}^{-1}\right)$ and $x=$ body mass $(g)$. We computed mean energy densities of puffin diets by area using summer values for capelin $\left(4.9 \mathrm{~kJ} \mathrm{~g}^{-1}\right)$, lesser sandlance Ammodytes marinus (4.9 $\mathrm{kJ} \mathrm{g}^{-1}$ ), and whiting Merlangius merlangus, an Atlantic gadoid, $\left(4.0 \mathrm{~kJ} \mathrm{~g}^{-1}\right)$ (Montevecchi \& Piatt 1984 , Hislop et al. 1991). (4) A tufted puffin chick consumes $6400 \mathrm{~g}$ of food from hatching to fledging. The estimate is based on food consumption (3634 g) by young Atlantic puffins adjusted for the larger size of tufted puffin chicks (496 g vs $284 \mathrm{~g}$ at fledging; Harris 1978 , Wehle 1980). (5) On average, about $80 \%$ of the puffins in Alaskan colonies produce eggs, mean hatching success is $64 \%$, and fledging success averages $74 \%$ (Byrd et al. in press).

Data on pollock use in all 3 areas are available from 1986. The calculations for Area 3 are summarized in Figure 13. We use a value of $68 \%$ pollock in the puffins' diet, which is the mean percentage observed at 3 colonies in the area (Midun, Aiktak, and Tangagm). About 25000 metric $t$ of food were consumed in Area 3 over the chick-rearing period, of which about 17600 metric $t$ were pollock. Based on the mean fresh weight of individual pollock observed in this study $(1.6 \mathrm{~g})$, that is equivalent to $10.7 \times 10^{9}$ juvenile pollock removed by puffins. Similar calculations for Area 1 (1\% dietary pollock; Table 5) and Area 2 (6\% pollock observed at Suklik and Egg Islands in 1986) give respective estimates of 84 metric $t$ and 440 metric $t$ of pollock consumed from mid July to mid September. Total pollock mortality from tufted puffin predation throughout the Gulf is estimated at 11.0 billion juveniles. 
Table 6. Theragra chalcogramma. Growth rate estimates for Age 0 pollock in the Gulf of Alaska, 1985-1987

\begin{tabular}{|c|c|c|c|c|c|c|}
\hline \multirow[t]{2}{*}{ Year } & \multirow[t]{2}{*}{ Dates } & \multirow[b]{2}{*}{ Slope $\left(\mathrm{mm} \mathrm{d}^{-1}\right)$} & \multicolumn{3}{|c|}{ Regression estimates } & \multirow[t]{2}{*}{ Method } \\
\hline & & & n & $r^{2}$ & $\mathrm{p}<$ & \\
\hline 1985 & 17 Aug - 26 Aug & 1.15 & $400 \mathrm{fish}$ & 0.09 & 0.000 & Suklik I. longitudinal estimate \\
\hline 1986 & 12 Aug - 2 Sep & 0.59 & 5 sites & 0.86 & 0.02 & Regression of area mean lengths \\
\hline 1987 & $31 \mathrm{Jul}-26$ Aug & 1.09 & 43 fish & 0.21 & 0.002 & Suklik I. longitudinal estimate \\
\hline 1987 & 27 Aug - 5 Sep & 0.49 & 492 fish & 0.03 & 0.000 & Aiktak I. longitudinal estimate \\
\hline 1987 & 9 Aug - 1 Sep & 0.58 & 3 sites & 0.85 & 0.25 & Regression of area mean lengths \\
\hline
\end{tabular}

\section{Predicting pollock year-class strength}

The proportion of pollock in tufted puffin diets at the Semidi Islands was relatively high $(21 \%)$ in 1985 and low $(5 \%)$ in 1986 and 1987 . Trawl surveys for young of the year conducted by the National Marine Fisheries Service in September 1985-1987 provide similar estimates of relative cohort size (Table 7 ). There is agreement as well with the results of a 1989 bottom trawl survey indicating the relative abundance of fish aged 2 to 4 yr. Finally, there is close correspondence with model estimates of pollock cohort size based on survey results and information on fishing mortality (Hollowed \& Megrey 1990). Models give different estimates of absolute abundance depending on the type of survey data (hydroacoustic or bottom trawl) used for calibration. In either case, the relative measures of fishable stock size were accurately predicted by puffin diets at the Semidis.

\section{DISCUSSION}

Variation in puffin nestling diets can be interpreted from both the avian and fisheries points of view. From the standpoint of puffin ecology, differences among colonies in the age composition of prey are noteworthy because of the fluctuations in cohort size that occur in fishes like capelin and sandlance (Hart 1974, May 1974). We sampled colonies around Kodiak in 1 year only, but an earlier study (Baird 1990) also showed a prevalance of older sandlance and capelin at Cathedral Island in 1977 and 1978. If that pattern is typicai, it implies that a strong or weak year-class of prey would potentially affect all colonies, but not in the same years. As a corollary, one would expect puffin colonies with a greater variety of species and age groups of prey available to show less variability in chick-rearing success than those with a simpler prey base. The difference between puffin species - tufted puffins

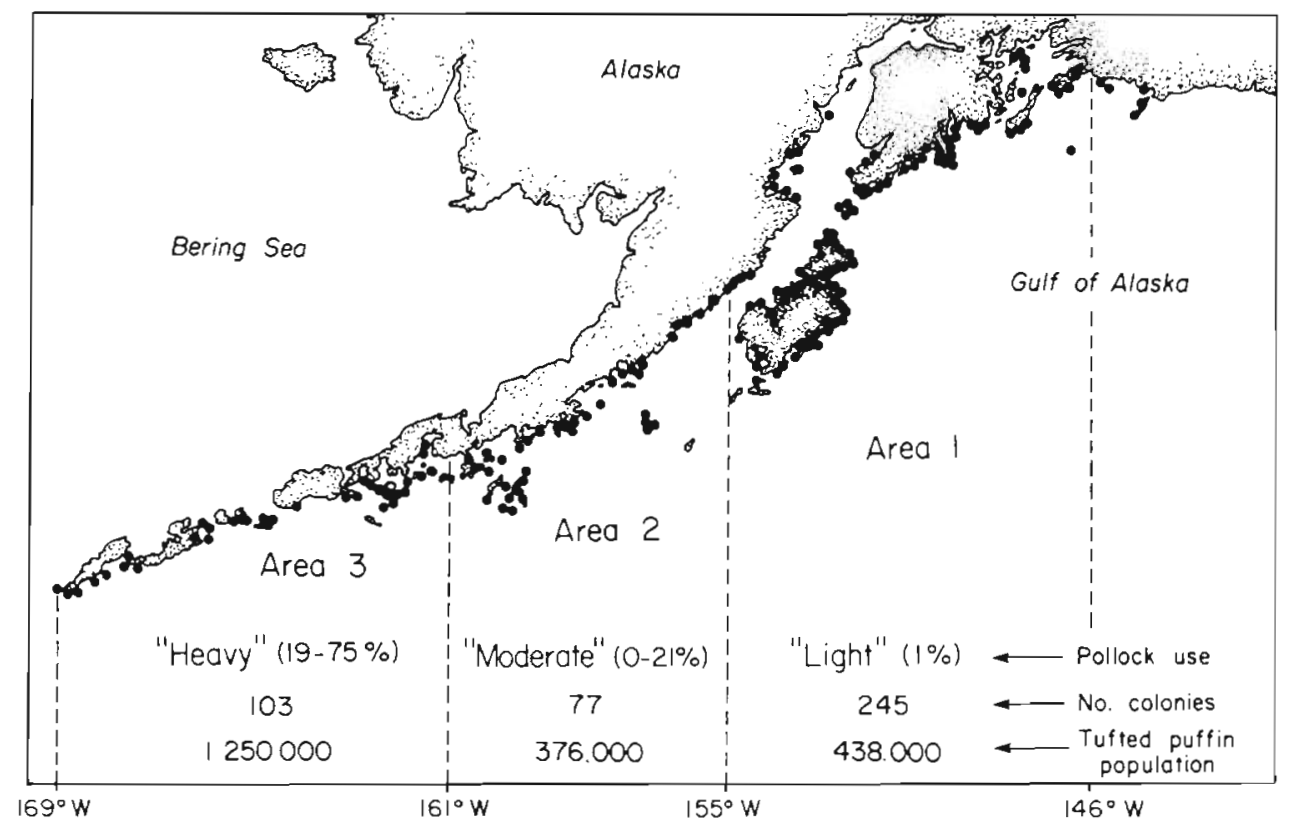

Fig. 12. Fratercula cirrhata, Theragra chalcogramma. Distribution of colonies, abundance, and pollock use by tufted puffins in the western Gulf of Alaska. Information on puffin numbers from Sowls et al. (1978) and unpubl. data of the U.S. Fish and Wildlife Service 


\section{TUFTED PUFFIN POLLOCK CONSUMPTION}

(AREA 3, MID JULY TO MID SEPTEMBER)

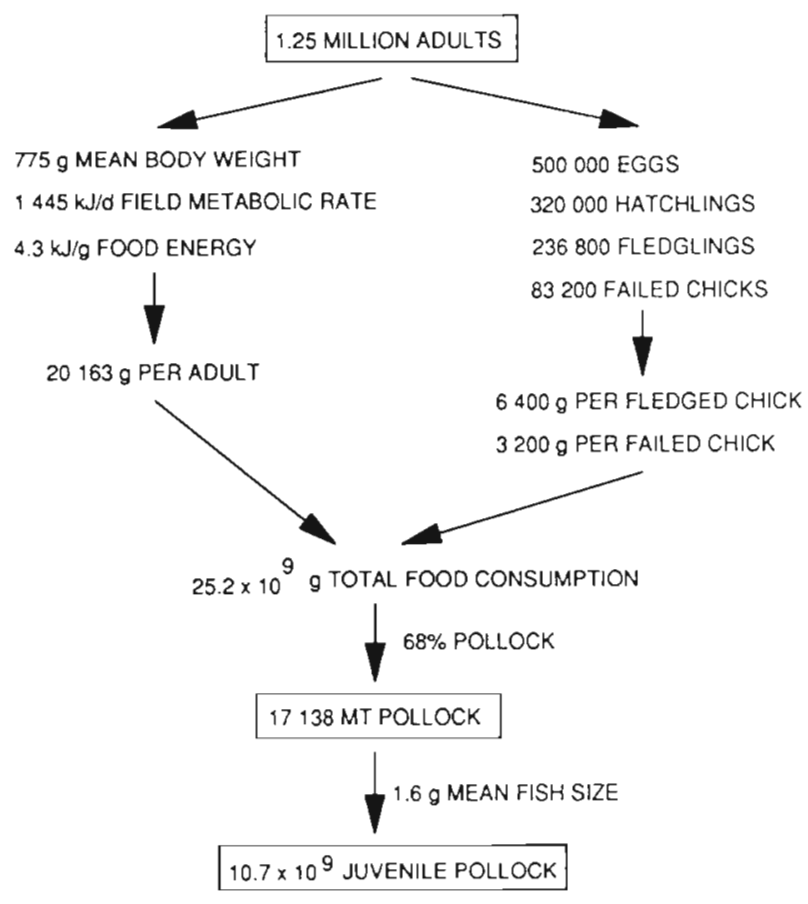

Fig. 13. Fratercula cirrhata, Theragra chalcogramma. Computation of pollock consumption during chick rearing by tufted puffins in 1986, Area 3 - Sandman Reefs through the eastern Aleutians. Chicks that fail are assumed to eat half the food supplied over a $46 \mathrm{~d}$ fledging period

taking a greater variety of prey, including invertebrates, and horned puffins specializing on forage fish - implies that tufted puffins may be similarly buffered against changes in prey resources.

The energy densities of different prey also have implications for puffin breeding biology. Pollock and other gadids typically have lower calorific values than fattier fish such as capelin and sandlance (Perez 1990. Hislop et al. 1991). Other factors being equal, puffins in colonies that rely on pollock would have to work harder to deliver a given amount of energy to their young. That possibility is consistent with intercolony differences in diet and field metabolic rates in other avian piscivores (Montevecchi \& Barrett 1987) and planktovores (Montevecchi et al. in press).

The interactions between seabirds and commercial fishing are usually considered by asking (a) whether fisheries adversely affect seabirds through competition for a common prey resource, (b) whether seabirds remove a significant portion of potentially harvestable fish stocks, and/or (c) whether seabirds can furnish information of use to fishery managers. As for (a), there are several affirmative examples worldwide (Schaefer 1970, Crawford \& Shelton 1978, Barrett et al. 1987, Vader et al. 1990), but puffins are probably not threatened by pollock fisheries in Alaska for 3 reasons. First, our information indicates that puffins eat only juvenile pollock, which are not harvested. Second, adult pollock are consumers of juvenile pollock (Dwyer et al. 1987) and also eat other seabird prey such as capelin and sandlance (Straty \& Haight 1979). Finally, the spawner-recruit relationship for pollock may be inverse over a wide range of adult pollock densities (Hollowed \& Megrey 1990). Short of a severe depletion of spawning females, then, the fishery could benefit puffins by removing potential competitors for juvenile pollock and other forage fish.

We estimated that puffins consumed about 11 billion pollock during chick-rearing in the Gulf of Alaska and eastern Aleutians in 1986. That is possibly an overestimate because it assumes there were similar proportions of pollock in adult and chick diets and that pollock use was constant from mid July to mid September. Although we detected no trends during extended visits to Suklik Island and Aiktak Island in 1987, seasonal shifts in prey use have been noted in other studies of puffin chick feeding (e.g. Hatch 1984 Vermeer \& Westrheim 1984).

The amount of predation attributable to puffins may or may not be substantial in relation to other sources of

Table 7. Theragra chalcogramma. Estimates of pollock year-class strength for the Gulf of Alaska, 1985-1987 ${ }^{\text {a }}$

\begin{tabular}{|c|c|c|c|c|c|}
\hline \multirow[t]{2}{*}{ Year-class } & \multirow{2}{*}{$\begin{array}{l}\text { Tufted puffin } \\
\text { diet Semidi Is. } \\
\text { (\% weight) }\end{array}$} & \multirow{2}{*}{$\begin{array}{l}\text { Fall } Y-O-Y \text { survey } \\
\text { (abundance index, } \\
\left.\qquad \times 10^{9}\right)^{b}\end{array}$} & \multirow{2}{*}{$\begin{array}{l}1989 \text { bottom } \\
\text { trawl survey } \\
(\% \text { at age })^{c}\end{array}$} & \multicolumn{2}{|c|}{$\begin{array}{c}\text { Stock synthesis model } \\
\text { estimates }\left(\times 10^{9}\right)^{c}\end{array}$} \\
\hline & & & & Model $A^{d}$ & Model Be \\
\hline 1985 & $20.7(0.668)$ & $22.1(0.580)$ & $21.4(0.686)$ & $2.010(0.707)$ & $0.589(0.738)$ \\
\hline 1986 & $5.2(0.168)$ & $6.2(0.163)$ & $4.2(0.135)$ & $0.426(0.150)$ & $0.120(0.150)$ \\
\hline 1987 & $5.1(0.165)$ & $9.7(0.257)$ & $5.6(0.179)$ & $0.406(0.143)$ & $0.089(0.112)$ \\
\hline \multicolumn{6}{|c|}{$\begin{array}{l}\text { a Standardized values in parentheses obtained by dividing each measurement by its respective column total } \\
\text { b Young of the year (Y-O-Y) survey data from Bailey \& Spring (in press) } \\
\text { c From Hollowed \& Megrey (1990) } \\
\text { d Model emphasis on bottom trawl survey results }\end{array}$} \\
\hline
\end{tabular}


juvenile pollock mortality. For perspective, it is estimated that 400 billion juveniles are consumed annually by adult pollock in the eastern Bering Sea (Dwyer et al. 1987). Predation by puffins is perhaps of greater relative importance in the Gulf of Alaska, where there are fewer pollock and lower rates of cannibalism (Hollowed \& Megrey 1990). As a rough estimate, puffins may remove about one-tenth of the Age 0 stock existing in the Gulf during early July, or 10 times the number of fish surviving the following March (Fig. 14). There are indications that puffins in winter continue to prey on juvenile pollock, and that other seabirds are also consumers of pollock in summer and fall (J. F. Piatt unpubl.). In the aggregate, seabirds may thus have a considerable influence on the early life history of pollock in the Gulf. In a comparable system, cormorants Phalacrocorax carbo and shags $P$, aristotelis were found to be a possible limiting factor for the recruitment of cod Gadus morhua into severely reduced but commercially important stocks in the Norwegian and Barents Seas (Barrett et al. 1990).

The use of seabirds as indicators of fish stocks is frequently suggested (Anderson et al. 1980, sunada et al. 1981, Crawford et al. 1983, Cairns 1987, Montevecchi \& Berruti 1991) but difficult to carry beyond the conceptual stage (Berruti 1985). We are optimistic that puffins can provide useful information on walleye pollock in at least 3 categories - the regional distribution of late summer juveniles, daily growth increments, and early indications of year-class strength. Because puffin colonies are numerous throughout the Gulf (Fig. 12), there is no shortage of sampling sites to choose for monitoring the spatial distribution of

GULF OF ALASKA POLLOCK SURVIVORSHIP

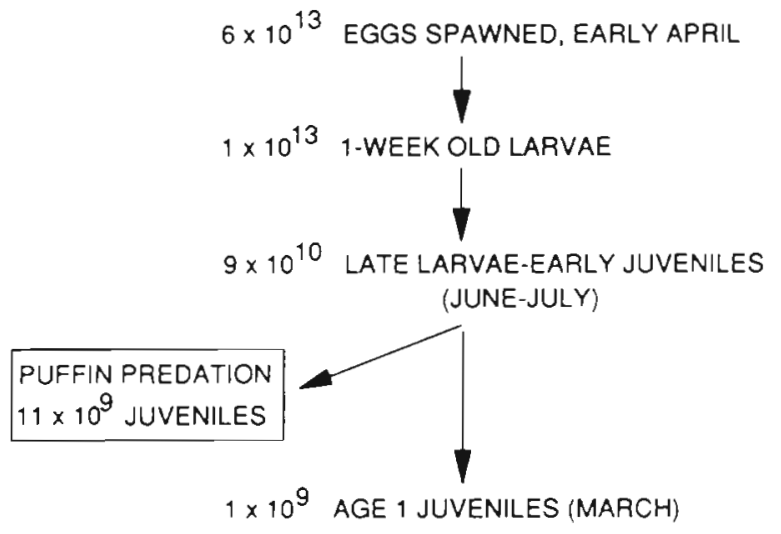

Fig. 14. Theragra chalcogramma. Relative role of puffin predation in the early life history of walleye pollock in the Gulf of Alaska. Estimates of pollock abundance, which pertain to the spawning stock of Shelikof Strait, are from Kendall \& Incze (unpubl.) and Hinckley et al. (1991) juvenile pollock. By mid July, the emergence of schooling behavior makes it difficult to monitor juvenile fish by conventional acoustic or net sampling methods (Hinckley et al. 1991). In contrast, puffins appear to be effective samplers at this stage, and indeed may not begin to exploit pollock until they aggregate in schools. Genetic studies of the pollock delivered by puffins in different colonies could help in discriminating spawning stocks and delineating their nursery areas.

We have greater confidence in our estimates of pollock growth from fixed locations than those based on multiple sites (Table 6). Both values from Suklik Island (1.09 and $1.15 \mathrm{~mm}$ day $\left.^{-1}\right)$ are considerably higher than any reported by Walline (1983) for Alaskan pollock in 4 years, 1978 through 1981 (range 0.34 to 0.69 , mean $0.55 \mathrm{~mm} \mathrm{day}^{-1}$ from hatching to 25 to $100 \mathrm{~mm}$ standard length). Our values, of course, do not incorporate the slower growth that occurs in the larval stage. For age-specific measures of growth, repeated sampling of pollock in puffin food loads from one location would seem to be a valid technique that avoids the tedious determination of daily growth increments in otoliths (Walline 1983).

The heaviest use of pollock was in the westernmost colonies, which are downstream from the Shelikof Strait spawning area and may be drawing from the juvenile stock produced there. Recent surveys have indicated the nursery area for late larval and early juvenile Shelikof pollock (June-July) is primarily between the Semidi and Shumagin Islands and that older juveniles (August-September) are abundant west of the Shumagins in some years (Hinckley et al. 1991). It is possible, however, that pollock taken in the area from the Sandman Reefs to Unimak Pass arise from other spawning aggregations, smaller than the Shelikof stock but locally important to puffins. For example, a sizeable spawning stock was discovered recently on the Davidson Bank, south of Unimak Pass (V.G. Westpestad pers. comm.).

Our provisional test of puffin diets as an indicator of juvenile pollock abundance uses data from the Semidi Islands, the only site visited in all 3 years. The Semidis are thought to be within the main nursery area for pollock produced in Shelikof Strait, and estimates of seasonal pollock abundance are available from recent fishery research in the area (Kendall et al. 1987. Kendall \& Picquelle 1989, Schumacher \& Kendall 1989 , Hinckley et al. 1991).

The apparent correlation of year-class strength and pollock deliveries by puffins at the Semidis is encouraging, but further study is needed to show whether puffin diets can provide a reliable index of Age 0 pollock abundance. The relationship would not necessarily be expected. If puffins take prey in proportion to 
their relative abundances, a decrease in pollock could signal either a decline in the absolute abundance of that species or an increase of alternative prey such as capelin or sandlance. Preferential feeding by puffins over a range of prey densities might further complicate the problem of inferring prey dynamics (Berruti 1985, Piatt 1987). Some of those potential problems could be overcome by quantifying rates of food delivery as well as diet composition (e.g. Ashcroft 1979). The time frame for sampling afforded by puffins is good because Bailey \& Spring (in press) found that of 2 alternative abundance indices they examined (larvae and Age 0 juveniles) the cohort strength of first-year pollock in late summer was most effective for predicting recruitment at Age 2.

Acknowledgements. The success of this project depended greatly on the efforts of those who assisted with the field collections and laboratory analysis of puffin food samples: D. Breese, D. Blomstrom, L. Catlin, A. DeGange, J. Harding, D. Irons, S. Lane, J. Nelson, M. North, M. Rossi, A. Sowls, U. Swain, G. Taber, B. Tershy, L. Terwilliger, and L. van Hulsteyn. Essential logistical support was provided by $\mathrm{Cmdr}$ D. MacKenzie and crew of the U.S. Coast Guard Cutter 'SEDGE' We are grateful to the staffs of the Kodiak, Izembek, and Alaska Maritime national wildlife refuges for hospitality and assistance. Special thanks also go to village residents and officials of Akhiok-Kaguyak, Inc., the Old Harbor Tribal Council, the Ouzinkie Native Corporation, and the Unga Corporation for hospitality and permission to work on their lands. We thank A. Kendall and H. Shippen, National Marine Fisheries Service, Alaska Fisheries Science Center, for their encouragement and interest in the project. B. Vinter, also of AFSC, ably identified our voucher specimens of puffin prey. The manuscript benefited from the comments of J. F. Piatt and K. M. Bailey.

\section{LITERATURE CITED}

Anderson, D. W., Gress, F., Mais, K. F., Kelly, P. R. (1980). Brown pelicans as anchovy stock indicators and their relationships to commercial fishing. Calif Coop. oceanic Fish. Invest. Rep. 22: 54-61

Anker-Nilssen, T (1987). The breeding performance of puffins Fratercula arctica on Rost, northern Norway in 1979-1985. Fauna norv. (Ser. C) Cinclus 10: 21-38

Anker-Nilssen, T., Lorentsen, S.-H. (1990). Distribution of puffins Fratercula arctica feeding off Rost, northern Norway, during the breeding season, in relation to chick growth, prey and oceanographical parameters. Polar Research 8: 67-76

Ashcroft, R. E. (1979). Survival rates and breeding biology of puffins on Skomer Island, Wales. Ornis Scand. 10 $100-110$

Bailey, K. M., Spring, S. (in press). Comparison of larval, age0 juvenile, and age- 2 recruit abundance indices of walleye pollock Theragra chalcogramma in the western Gulf of Alaska. J. Cons. int. Explor. Mer

Baird, P. (1990). Influence of abiotic factors and prey distribution on diet and reproductive success of three seabird species in Alaska. Ornis Scand. 21: 224-235
Barrett, R. T., Anker-Nilssen, T., Rikardsen, F., Valde, K., Rov, N., Vader, W. (1987). The food growth and fledging success of Norwegian puffin chicks Fratercula arctica in 1980-1983. Ornis Scand. 18: 73-83

Barrett, R. T., Rov, N., Loen, J., Montevecchi, W. A. (1990). Diets of shags Phalacrocorax aristotelis and cormorants $P$ carbo in Norway and possible implications for gadoid stock recruitment. Mar. Ecol. Prog. Ser. 66: 205-218

Berruti, A. (1985). The use of cape gannets Morus capensis in management of the purse-seine fishery of the Western Cape. Ph.D. thesis, University of Natal, South Africa

Birt-Friesen, V. L., Montevecchi, W. A., Cairns, D. K., Macko, S. A. (1989). Activity specific metabolic rates of free-living northern gannets and other seabirds. Ecology 70: 357-367

Byrd, G. V., Murphy, E. C., Kaiser, G. W., Kondratyev, A. J., Shibaev, Y. V. (in press). Status and ecology of offshore fish-feeding alcids (murres and puffins) in the North Pacific ocean. In: Vermeer, K., Briggs, K. T., SiegelCausey, D. (eds.) Ecology and conservation of marine birds of the temperate North Pacific. Can. Wildl. Serv. Spec. Pub., Ottawa

Cairns, D. K. (1987). Seabirds as indicators of marine tood supplies. Biol. Oceanogr. 5: 261-271

Corkhill, P. (1973). Food and feeding ecology of puffins. Bird Study 20: 207-220

Crawford, R. J. M., Shelton, P. A. (1978). Pelagic fish and seabird interrelationships of the coasts of South West and South Africa. Biol. Conserv. 14: 85-109

Crawford, R. J. M., Shelton, P. A., Berruti, A. (1983). Cape cormorants as potential indicators of pelagic fish stocks off southern Africa. S. Afr. J. Sci. 79: 466-468

Dick, M. H., Warner, I. M. (1982). Pacific sand lance, Ammodytes hexapterus Pallas, in the Kodiak Island group, Alaska. Syesis 15: 43-50

Dwyer, D. A., Bailey, K. M., Livingston, P. A. (1987). Feeding habits and daily ration of walleye pollock (Theragra chalcogramma) in the eastern Bering Sea, with special reference to cannibalism. Can. J. Fish. Aquat. Sci. 44: $1972-1984$

Harris, M. P. (1978). Supplementary feeding of young puffins, Fratercula arctica. J. Anim. Ecol. 47: 15-23

Harris, M. P., Hislop, J. R. G. (1978). The food of young puffins, Fratercula arctica. J. Zool., Lond. 185: 213-236

Hart, J. L. (1973). Pacific fishes of Canada. Bull. Fish. Res. Bd Can. 180

Hart, P. J. B. (1974). The distribution and long term changes in abundance of larval Ammodytes marinus (Raitt) in the North Sea. In: Blaxter, J. H. S. (ed.) The early life history of fish. Springer-Verlag, Berlin, p. 171-182

Hatch, S. A. (1984). Nestling diet and feeding rates of rhinoceros auklets in Alaska. In: Nettleship, D. N., Sanger, G. A., Springer, P. F. (eds.) Marine birds: their feeding ecology and commercial fishery relationships. Can. Wildl. Serv. Spec. Pub., Ottawa, p. 106-115

Hatch, S. A., Hatch, M. A. (1983). Populations and habitat use of marine birds in the Semidi Islands, Alaska. Murrelet 64 : $39-46$

Hinckley, S., Bailey, K. M., Picquelle, S. J., Schumacher, J. D., Stabeno, P. J. (1991). Transport, distribution, and abundance of larval and juvenile walleye pollock (Theragra chalcogramma) in the western Gulf of Alaska. Can. J. Fish. Aquat. Sci. 48: 91-98

Hislop, J. R. G., Harris, M. P., Smith, J. G. M. (1991). Variation in the calorific value and total energy content of the lesser sandeel (Ammodytes marinus) and other fish preyed on by seabird5. J. Zool., Lond. 224: 501-517

Hollowed, A. B., Megrey, B. A. (1990). Walleye pollock. In: 
Stock assessment and fishery evaluation report for the 1991 Gulf of Alaska groundfish fishery. North Pac. Fish. Mgmt. Council, Anchorage, Alaska, p. 22-89

Kendall, A. W., Jr, Clarke, M. E., Yoklavich, M. M., Boehlert, G. W (1987). Distribution, feeding, and growth of larval walleye pollock, Theragra chalcogramma, from Shelikof Strait, Gulf of Alaska. Fish. Bull. U.S. 85: 499-521

Kendall, A. W., Jr, Picquelle, S. J. (1989). Egg and larval distributions of walleye pollock Theragra chalcogramma in Shelikof Strait, Gulf of Alaska. Fish. Bull. U.S. 88: $133-154$

Lloyd, D. S., Davis, S. K. (1989). Biological information required for improved management of walleye pollock off Alaska. In: International symposium on the biology and management of walleye pollock. Lowell Wakefield Fish. Symp. 7. Alaska Sea Grant Rep. 89-1, p. 9-31

Martin. A. R. (1989). The diet of Atlantic puffin Fratercula arctica and northern gannet Sula bassana chicks at a Shetland colony during a period of changing prey availability. Bird Study 36: 170-180

May, R. C. (1974). Larval mortality in marine fishes and the critical period concept. In: Blaxter, J. H. S. (ed.) The early life history of fish. Springer-Verlag, Berlin, p. 3-19

Montevecchi, W. A., Barrett, R. T (1987). Prey selection by gannets at breeding colonies in Norway. Ornis Scand. 18: $319-322$

Montevecchi, W. A., Birt-Friesen, V. L., Cairns, D. K. (in press). Reproductive energetics and prey harvests of Leach's storm-petrels in the northwest Atlantic. Ecology

Montevecchi, W. A., Piatt, J. (1984). Composition and energy contents of mature inshore spawning capelin (Mallotus villosus): implications for seabird predators. Comp. Biochem. Physiol. 78: 15-20

Montevecchi, W. A., Berruti, A. (1991). Avian indication of pelagic fishery conditions in the southeast and northwest Atlantic. Internatl. Ornithol. Congr. 20: 2246-2256

Nettleship, D. N. (1990). The diet of Atlantic puffin chicks in Newfoundland before and after the initiation of an international capelin fishery, 1967-1984. Internatl. Ornithol. Congr. 20: 2263-2271

Pahlke, K. A. (1985), Life history and distribution of capelin, Mallotus villosus, in Alaskan waters. M.S. thesis, Univ. Alaska, Juneau

Perez, M. A. (1990). Review of marine mammal population and prey information for Bering Sea ecosystem studies. U.S. Dep. Comm., NOAA Tech. Memo., NMFS F/NWC-184

This article was presented by Dr R. W. Furness, Glasgow, Scotland
Piatt, J. F. (1987). Behavioural ecology of common murre and Atlantic puffin predation on capelin: implications for population biology. Ph.D. thesis, Memorial Univ. of Newfoundland, St. John's

Schaefer, M. B. (1970). Men, birds and anchovies in the Peru current - dynamic interactions. Trans. Am. Fish. Soc. 9: $461-467$

Schumacher, J. D., Kendall, A. W., Jr (1989). Fisheries oceanography coordinated investigations (FOCI): walleye pollock recruitment in the western Gulf of Alaska. In: Jarvela, L. E., Thorsteinson, L. K. (eds.) Proceedings of the Gulf of Alaska, Cook Inlet, and north Aleutian Basin information update meeting. U.S. Dept. Comm., NOAA, OCS Study MMS 89-0041, Anchorage, p. 39-47

Sowls, A. L., Hatch, S. A., Lensink, C. J. (1978). Catalog of Alaskan seabird colonies. U.S. Dept. Interior, Fish and Wildl. Serv., FWS/OBS-78/78

Straty, R. R., Haight, R. E. (1979). Interactions among marine birds and commercial fish in the eastern Bering Sea. In: Bartonek, J C., Nettleship, D. N. (eds.) Conservation of marine birds of northern North America. U.S. Fish Wildl. Serv., Wildlife Res. Rep. 11, p. 201-219

Sunada, J. S., Kelly, P. R., Yamashita, I. S., Gress, F. (1981). The brown pelican as a sampling instrument of age group structure in the northern anchovy population. Calif. Coop. oceanic Fish. Invest. Rep. 22:65-68

Vader, W., Barrett, R. T., Erikstad, K. E., Strann, K.-B. (1990). Differential responses of common and thick-billed murres to a crash in the capelin stock in the southern Barents Sea. Stud. avian Biol. 14: 175-180

Vermeer, K., Westrheim, S. J. (1984). Fish changes in diets of nestling rhinoceros auklets and their implications. In: Nettleship, D. N., Sanger, G. A., Springer, F. F. (eds.) Marine birds: their feeding ecology and commercial fishery relationships. Can. Wildl. Serv. Spec. Pub., Ottawa, p. $96-105$

Walline, P. D. (1983). Growth of larval and juvenile walleye pollock related to year-class strength. Ph.D. thesis, Univ. Washington, Seattle

Wehle, D. H. S. (1980). The breeding biology of the puffins: tufted puffin (Lunda cirrhata), horned puffin (Fratercula corniculata), and Rhinoceros Auklet (Cerorhinca monocerataj. Ph.D. thesis, Univ. Alaska, Fairbanks

Wehle, D. H. S. (1983). The food, feeding, and development of young tufted and horned puffins in Alaska. Condor 85: $427-442$

Manuscript first received: October 3, 1991

Revised version accepted: January 9, 1992 